\title{
OPEN A sulfate-reducing bacterial genus, Desulfosediminicola gen. nov., comprising two novel species cultivated from tidal-flat sediments
}

\author{
Jaeho Song ${ }^{1,2,3}$, Juchan Hwang ${ }^{2,3}$, Ilnam Kang ${ }^{2}$ \& Jang-Cheon Cho ${ }^{2 \bowtie}$
}

Tidal-flat sediments harbor a diverse array of sulfate-reducing bacteria. To isolate novel sulfatereducing bacteria and determine their abundance, a tidal-flat sediment sample collected off Ganghwa Island (Korea) was investigated using cultivation-based and culture-independent approaches. Two Gram-stain-negative, strictly anaerobic, rod-shaped, sulfate-reducing bacteria, designated IMCC $35004^{\top}$ and IMCC $35005^{\top}$, were isolated from the sample. The two strains reduced sulfate, sulfite, elemental sulfur, thiosulfate, $\mathrm{Fe}$ (III) citrate, and $\mathrm{Mn}$ (IV) oxide by utilizing several carbon sources, including acetate. The $16 \mathrm{~S}$ rRNA gene amplicon sequencing revealed that the tidal-flat sediment contained diverse members of the phylum Desulfobacterota, and the phylotypes related to IMCC $35004^{\top}$ and IMCC $35005^{\top}$ were $<1 \%$. The two strains shared $97.6 \%$ similarity in $16 \mathrm{~S}$ rRNA gene sequence and were closely related to Desulfopila aestuarii DSM $18488^{\top}(96.1-96.5 \%)$. The average nucleotide identity, level of digital DNA-DNA hybridization, average amino acid identity, and percentages of conserved proteins determined analyzing the whole-genome sequences, as well as the chemotaxonomic data showed that the two strains belong to two novel species of a novel genus. Additionally, genes related to dissimilatory sulfate reduction were detected in the genomes of the two strains. Unlike the genera Desulfopila and Desulfotalea, IMCC $35004^{\top}$ and IMCC $35005^{\top}$ contained menaquinone- 5 as the major respiratory quinone. Collectively, IMCC $35004^{\top}$ and IMCC $35005^{\top}$ were concluded to represent two novel species of a novel genus within the family Desulfocapsaceae, for which the names Desulfosediminicola ganghwensis gen. nov., sp. nov. (IMCC35004 ${ }^{\top}=\mathrm{KCTC}$ $15826^{\top}=$ NBRC $\left.114003^{\top}\right)$ and Desulfosediminicola flagellatus sp. nov. $\left(\right.$ IMCC $35005^{\top}=\mathrm{KCTC}$ $15827^{\top}=$ NBRC $114004^{\top}$ ) are proposed.

Sulfate-reducing bacteria (SRB) are defined by their ability to use sulfate as a terminal electron acceptor during anaerobic respiration, and they are known to be universally found in anoxic habitats, including marine sediments, soil, groundwater, active sludge, and animal guts ${ }^{1-5}$. SRB are particularly ubiquitous and abundant in anoxic marine sediments, accounting for up to $10-30 \%$ of the corresponding bacterial community ${ }^{6-8}$. Sulfate reduction, mediated by diverse groups of SRB, accounts for $>50 \%$ of the carbon re-mineralization in coastal sediments ${ }^{9}$, thereby constituting one of the most important metabolic processes accounting for the anaerobic degradation of the organic matter in anoxic marine sediments.

SRB and sulfate-reducing archaea are phylogenetically widespread, distributed among at least three phyla within the domain Bacteria (Desulfobacterota, Nitrospirota, and Firmicutes) and two classes of the domain Archaea (Archaeoglobi and Thermoproteia), respectively ${ }^{10,11}$. Of these, the phylum Desulfobacterota ${ }^{11}$ harbors $>80$ genera of sulfate-reducing bacteria (https://lpsn.dsmz.de), representing the largest phylum harboring SRB. Among the many families of the phylum Desulfobacterota, the family Desulfocapsaceae was first proposed by Waite et al. ${ }^{11}$ via the reclassification of the family Desulfobulbaceae based on phylogenetic analyses with 120 conserved single-copy marker genes and 16S rRNA gene. As of August 2021, the family embraces five genera, Desulfofustis ${ }^{12}$, Desulfocapsa $^{13}$, Desulforhopalus ${ }^{14}$, Desulfotalea ${ }^{15}$, and Desulfopila ${ }^{16}$, which have been identified from sewage sludge or marine, brackish, and freshwater sediments. Members of the family Desulfocapsaceae show various phenotypic characteristics, such as a wide temperature range for growth $\left(-1.8\right.$ to $\left.40^{\circ} \mathrm{C}\right)$, motile or non-motile property,

${ }^{1}$ Division of Microbiology, Honam National Institute of Biological Resources, 58762 Mokpo, Republic of Korea. ${ }^{2}$ Department of Biological Sciences, Inha University, Incheon 22212, Republic of Korea. ${ }^{3}$ These authors contributed equally: Jaeho Song and Juchan Hwang. ${ }^{\circledR}$ email: chojc@inha.ac.kr 
anaerobic chemolithotrophic or chemoheterotrophic metabolism, anaerobic respiratory or fermentative growth, and usage of various electron donors and acceptors for sulfate reduction. According to the EzBioCloud database, which holds quality-controlled bacterial genomes ${ }^{17}$, members of the family Desulfocapsaceae have a 3.5-6.1 Mb genome with $45.4-56.3 \% \mathrm{G}+\mathrm{C}$ content. The family is considered one of the major sulfate-reducing bacterial groups in anoxic marine sediments, often comprising up to $11 \%$ of the total bacterial community in a habitat ${ }^{8,18,19}$.

The coastal area of the Yellow Sea is characterized by the presence of vast tidal-flat sediments, where the families Desulfobulbaceae and Desulfocapsaceae have been abundantly detected via culture-independent analyses, but the members of the family have rarely been isolated ${ }^{20-22}$. This study reports the isolation of two sulfate-reducing bacterial strains of the family Desulfocapsaceae from a tidal-flat sediment of the Yellow Sea. Based on the distinct genomic and phenotypic characteristics, the two strains were considered to belong to two novel species of a new genus in the family Desulfocapsaceae.

\section{Results and discussion}

Phylogenetic and phylogenomic analyses. Two sulfate-reducing bacterial strains, designated IMCC $35004^{\mathrm{T}}$ and IMCC $35005^{\mathrm{T}}$, were isolated from a sediment sample collected off the west coast of Korean Peninsula during a study on the culturable anaerobic bacterial community of the tidal flat in the eastern margin of the Yellow Sea. Comparative sequence analyses using the almost complete $16 \mathrm{~S}$ rRNA gene sequences of strains IMCC $35004^{\mathrm{T}}$ and IMCC $35005^{\mathrm{T}}$ revealed that the two strains are affiliated with the family Desulfocapsaceae. The two strains were found to share $97.6 \%$ similarity in $16 \mathrm{~S}$ rRNA gene sequence, which is less than the proposed cut-off value of $98.7 \%$ for bacterial species demarcation ${ }^{23,24}$, suggesting that these strains belong to two separate species. Strains IMCC $35004^{\mathrm{T}}$ and IMCC $35005^{\mathrm{T}}$ were identified to show the highest $16 \mathrm{~S}$ rRNA gene sequence similarity with uncultured clone HS030 (JX391366; 99.7\%) and strain LS5B (LR792819; 99.9\%) retrieved from marine sediment. Among the validly published species, strains IMCC $35004^{\mathrm{T}}$ and IMCC $35005^{\mathrm{T}}$ were most closely related to Desulfopila aestuarii DSM $18488^{\mathrm{T}}$ (96.5 and 96.1\% 16S rRNA gene sequence similarity, respectively), followed by Desulfotalea psychrophila LSv54 $4^{\mathrm{T}}$ (95.7 and 95.9\%) and Desulfotalea arctica LSv514 ${ }^{\mathrm{T}}$ (95.8 and 95.9\%). Phylogenetic analysis based on the 16S rRNA gene sequences revealed that these two novel strains form a distinct and robust clade, with $92-98 \%$ bootstrap values, within the family Desulfocapsaceae (Fig. 1). The two strains formed a clade with the genus Desulfotalea (89-90\% bootstrap supports) and a large clade with Desulfopila aestuarii DSM $18488^{\mathrm{T}}$ (73-75\% bootstrap supports). In contrast to the $16 \mathrm{~S}$ RNA gene tree (Fig. 1), where strains IMCC $35004^{\mathrm{T}}$ and $\mathrm{IMCC} 35005^{\mathrm{T}}$ form a clade with the genus Desulfotalea, the phylogenomic tree based on the bacterial core-gene sets (Fig. 2) show that the two strains first cluster with Desulfopila aestuarii and form a clade with the genera Desulfotalea and Desulforhopalus. Thus, the two strains cannot be assigned to a specific genus.

The overall genome-relatedness indices supported that strains IMCC $35004^{\mathrm{T}}$ and IMCC $35005^{\mathrm{T}}$ belong to two separate species (Supplementary Table S1). The average nucleotide identity (ANI) and digital DNA-DNA hybridization $(\mathrm{dDDH})$ values between the two strains were estimated at $70.2 \%$ and $20.5 \%$, respectively, far below the ANI (95-96\%) and dDDH (70\%) thresholds proposed for bacterial species demarcation ${ }^{25,26}$. Accordingly, these two strains each represent a novel species. The values of average amino-acid identity (AAI) and percentage of conserved proteins (POCP) of the two strains and Desulfopila aestuarii DSM $18488^{\mathrm{T}}$ were calculated to be 67.3-69.6\% and 47.9-49.6\%, respectively (Supplementary Table S1), suggesting that the two strains may belong to the genus Desulfopila or a new genus since the values are marginally higher or lower than the AAI $(\sim 65 \%)$ and POCP (50\%) thresholds for genus delineation ${ }^{27,28}$. In contrast, the AAI and POCP values between the two strains and Desulfotalea psychrophila LSv54 ${ }^{\mathrm{T}}$ were calculated at $56.8-57.0 \%$ and $42.9-43.8 \%$, respectively, indicating that the two strains belong to a genus different from Desulfotalea.

Genomic characteristics. The genomes of strains IMCC $35004^{\mathrm{T}}$ and $\mathrm{IMCC} 3005^{\mathrm{T}}$ were estimated at $5,653,142$ and 6,751,878 bp, respectively, and comprise single circular chromosomes, (Supplementary Table S2; and Supplementary Figs. S1 and S2). The G + C content of IMCC $35004^{\mathrm{T}}$ and IMCC $35005^{\mathrm{T}}$ genomes was calculated to be 48.9 and $44.3 \%$, respectively (Table 1). IMCC $35004^{\mathrm{T}}$ and IMCC35005 ${ }^{\mathrm{T}}$ genomes were found to harbor 4715 and 5479 protein-coding, 73 and 76 tRNA, and 18 and 21 rRNA genes, respectively. Six and seven copies of 16S rRNA gene sequences were detected in IMCC $35004^{\mathrm{T}}$ and IMCC $35005^{\mathrm{T}}$ genomes, respectively. These copies showed $100 \%$ sequence similarity among themselves and with their Sanger-sequencing counterparts amplified using PCR.

The genomes of strains IMCC $35004^{\mathrm{T}}$ and $\mathrm{IMCC} 35005^{\mathrm{T}}$ were found to contain genes for diverse metabolic pathways, as presented in Fig. 3 and Supplementary Table S2. In accordance with the experimental results, IMCC $35004^{\mathrm{T}}$ and IMCC $35005^{\mathrm{T}}$ genomes were identified to contain all the genes necessary for dissimilatory reduction of sulfate to hydrogen sulfide ${ }^{32}$. The two genomes contain multiple (4-5) copies of SulP family sulfate permease genes, transporting $\mathrm{SO}_{4}{ }^{2-}$ across the cell membrane. Additionally, the two genomes harbor the following genes for dissimilatory sulfate reduction: sulfate adenylyltransferase (sat), adenosine- $5^{\prime}$-phosphosulfate reductase $(\operatorname{apr} A B)$, and dissimilatory sulfite reductase $(d s r A B)$. Gene clusters of quinone-interacting membranebound oxidoreductase $(q m o A B C)$ and sulfite reduction-associated complex protein ( $d s r M K J O P)$ genes, which are involved in the electron transport from membrane-bound protein pools to cytoplasmic reductases (AprAB and DsrAB), were detected in each genome. The gene $d s r C$, which couples sulfate reduction to energy conservation ${ }^{33}$, and the gene $d s r D$, which is usually found in sulfite-reducing bacteria but not in sulfur-oxidizing bacteria ${ }^{34}$, were also predicted in both genomes. These genes related to dissimilatory sulfate reduction are also found in Desulfopila and Desulfotalea genomes.

The four SRB genomes employed in this study for the comparative genomic analyses were identified to contain the genes involved in the Embden-Meyerhof-Parnas pathway, tricarboxylic acid cycle, and dissimilatory 


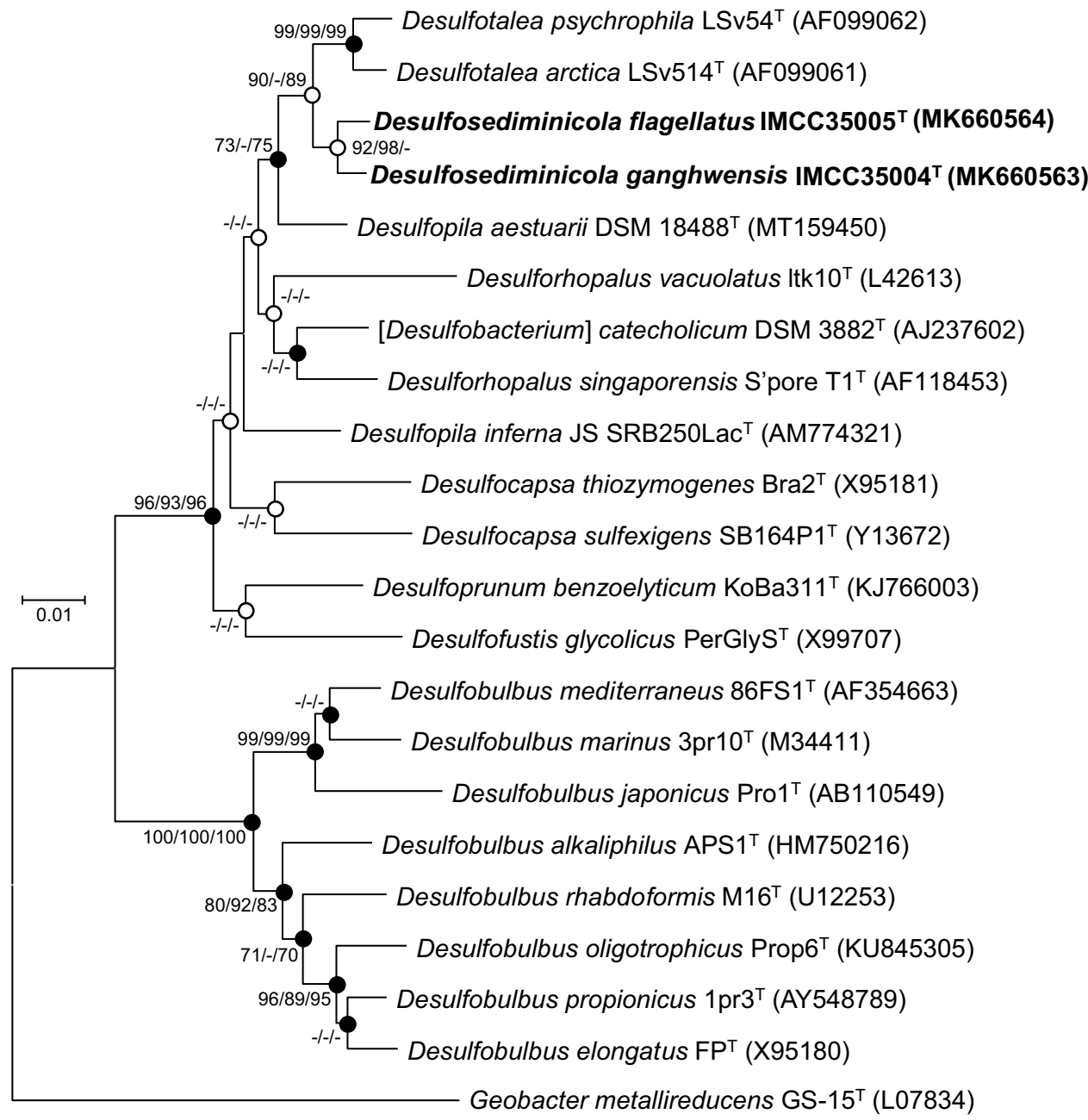

Figure 1. Positions of strains IMCC $35004^{\mathrm{T}}$ and $\mathrm{IMCC} 35005^{\mathrm{T}}$ on the neighbor-joining phylogenetic tree based on the $16 \mathrm{~S}$ rRNA gene sequences. Filled circles indicate that the corresponding nodes were identified from all the treeing methods. Open circles indicate the nodes identified from the two treeing methods. The bootstrap values (expressed as percentages of 1000 replications) are shown at nodes for neighbor-joining, minimumevolution, and maximum-likelihood methods; only the values $\geq 70 \%$ are shown. The GenBank/EMBL/DDBJ accession numbers are shown in parentheses. Geobacter metallireducens GS-15 ${ }^{\mathrm{T}}$ (L07834) was used as an outgroup. The bar represents 0.01 nucleotide changes per position.

sulfate and nitrate reduction, and also the genes encoding the ABC transporters for 4-amino-5-hydroxymethyl-2-methylpyrimidine (HMP)/ $N$-formyl-4-amino-5-aminomethyl-2-methylpyrimidine (FAMP), tungstate, molybdate, iron(III), glycine betaine/proline, phospholipid, phosphate, general L-amino acids, branched-chain amino acids, lipoprotein, and lipopolysaccharide (Fig. 3 and Supplementary Table S2). However, IMCC $35004^{\mathrm{T}}$ and IMCC $35005^{\mathrm{T}}$ genomes differ from Desulfopila and Desulfotalea genomes in harboring genes involved in the Wood-Ljungdahl pathway or encoding acetaldehyde dehydrogenase $(a d h E)$, formate dehydrogenase $(f d h A)$, lactoylglutathione lyase $(g l o A)$, sulfhydrogenase $(h y d G)$, sulfite dehydrogenase (sor $A B)$, hydroxylamine dehydrogenase ( $h a o)$, fumarylacetoacetase $(f a h A)$, and urocanate reductase (urdA). The gene clusters underlying flagellar assembly were detected in the genome of IMCC $35005^{\mathrm{T}}$ but not in IMCC $35004^{\mathrm{T}}$ genome, consistent with the transmission electron microscopy (TEM) results (Supplementary Fig. S3). The two genomes were predicted to harbor the genes related to the synthesis of phosphatidylglycerol ( $p s p A$ and $c d s A$ ) and phosphatidylethanolamine ( $p s d$ and $p s p B$ ). In corroboration, two-dimensional thin-layer chromatography (TLC) of polar lipids yielded the corresponding spots (Supplementary Fig. S4).

Based on the COG functional profile, strains IMCC $35004^{\mathrm{T}}$ and IMCC $35005^{\mathrm{T}}$ were found to have high proportions of genes $(>5.0 \%)$ related to energy production and conversion (9.3-10.0\% of all the COGs), signal transduction mechanisms (6.3-8.5\%), amino acid transport and metabolism (6.5-6.9\%), cell wall/membrane/ envelope biogenesis (5.3-5.7\%), general function prediction only (6.4-7.5\%), and function unknown (5.1-5.2\%), which are overall similar to those of the other two genomes from the family Desulfocapsaceae (Supplementary Table S3). Comparative genomic analyses using a Venn diagram (Supplementary Fig. S5) showed that the pangenome of the four Desulfocapsaceae strains contains 1647 conserved core genes. A total of 664 and 708 genes from IMCC $35004^{\mathrm{T}}$ and IMCC $35005^{\mathrm{T}}$, respectively, were found to be unique. 


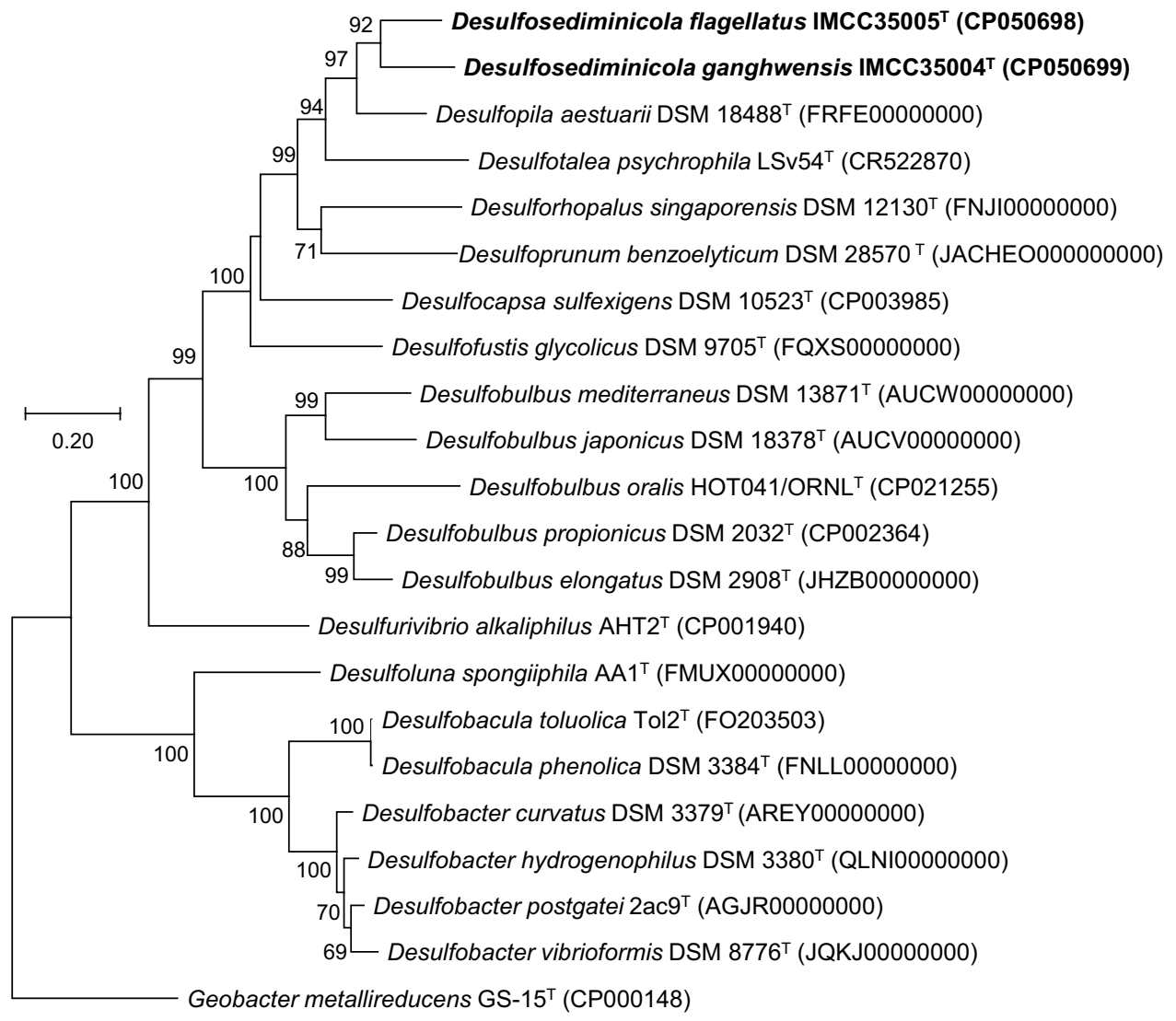

Figure 2. Positions of strains IMCC $35004^{\mathrm{T}}$ and $\mathrm{IMCC} 35005^{\mathrm{T}}$ on the phylogenetic tree based on the wholegenome sequences. A total of 29,457 amino acids were used for the phylogenomic analyses using up-todate bacterial core gene sets (UBCG). The genome accession numbers are shown in parentheses. Geobacter metallireducens GS-15T (CP000148) was used as an outgroup. The bootstrap supports are shown at the nodes. The bar represents 0.2 substitutions per position.

Phenotypic characteristics. The cells of strains IMCC $35004^{\mathrm{T}}$ and IMCC $35005^{\mathrm{T}}$ are Gram-stain-negative, chemoheterotrophic, strictly anaerobic, and rod-shaped. Both strains formed beige-colored, circular, convex, and smooth colonies with an entire margin and diameter of $0.4-0.7 \mathrm{~mm}$ after incubation on $3 \mathrm{M}-\mathrm{R} 2 \mathrm{~A}$ at $25^{\circ} \mathrm{C}$ for 3 weeks. The detailed phenotypic characteristics of strains IMCC $35004^{\mathrm{T}}$ and IMCC $35005^{\mathrm{T}}$ are provided in Tables 1, 2, 3, Supplementary Tables S4, and S5, and the protologues. Strains IMCC $35004^{\mathrm{T}}$ and $\mathrm{IMCC}_{35005^{\mathrm{T}}}$ differed in several phenotypic characteristics. The cells of strain IMCC $35004^{\mathrm{T}}$ were observed to be devoid of flagella, whereas those of strain IMCC $35005^{\mathrm{T}}$ harbored a polar flagellum (Supplementary Fig. S3), consistent with the results of the genomic analyses for the genes involved in flagella assembly. Both strains reduced sulfate, sulfite, elemental sulfur, thiosulfate, $\mathrm{Fe}(\mathrm{III})$ citrate, and $\mathrm{Mn}(\mathrm{IV})$ oxide but did not reduce nitrate or nitrite. Unlike strain IMCC $35004^{\mathrm{T}}$, strain IMCC $35005^{\mathrm{T}}$ reduced Fe(III) oxyhydroxide. Phenotypic characteristics of strains IMCC $35004^{\mathrm{T}}$ and IMCC $35005^{\mathrm{T}}$ were found to differ from those of other genera of the family Desulfocapsaceae, including the presence of flagella, growth range, and utilization of acetate as an electron donor, and sulfite as an electron acceptor (Table 1). Additionally, these two novel strains were found to differ from Desulfopila aestuarii DSM $18488^{\mathrm{T}}$ and Desulfotalea psychrophila DSM $12343^{\mathrm{T}}$ in hydrolysis of Tweens 20 and 80, enzyme activities, and carbon utilization patterns (Table 2, Supplementary Tables S4, and S5).

The fatty-acid profiles of IMCC $35004^{\mathrm{T}}$, IMCC $35005^{\mathrm{T}}$, Desulfopila aestuarii DSM $18488^{\mathrm{T}}$, and Desulfotalea psychrophila DSM $12343^{\mathrm{T}}$ are shown in Table 3 . The major cellular fatty acids $(>10 \%)$ of strain IMCC $35004^{\mathrm{T}}$ were $\mathrm{C}_{17: 1} \omega 6 c(21.6 \%), \mathrm{C}_{16: 0}(17.6 \%)$, and $\mathrm{C}_{16: 1} \omega 5 c(11.2 \%)$, and those of strain IMCC $35005^{\mathrm{T}}$ were $\mathrm{C}_{17: 1} \omega 6 c$ (23.4\%), $\mathrm{C}_{16: 0}(21.6 \%)$, summed feature $3\left(\mathrm{C}_{16: 1} \omega 7 c\right.$ and/or $\left.\mathrm{C}_{16: 1} \omega 6 c ; 16.3 \%\right)$, and $\mathrm{C}_{16: 1} \omega 5 c(12.3 \%)$, showing different proportions from those of the related type species. For example, although $\mathrm{C}_{17: 1} \omega 6 \mathrm{c}$ is highly found in strains IMCC 35004, IMCC35005, and DSM $18488^{\mathrm{T}}$, constituting $16.7-23.4 \%$ of the total cellular fatty acids, it was not detected in the genus Desulfotalea.

Strain IMCC 35004 ${ }^{\mathrm{T}}$ contains phosphatidylethanolamine (PE), phosphatidylglycerol (PG), and diphosphatidylglycerol (DPG) as the major polar lipids, whereas IMCC $35005^{\mathrm{T}}$ contains only PE and PG. These two polar lipids are consistently found in the genera Desulfopila and Desulfotalea, but the presence of DPG among the genera varies (Table 1). The predominant isoprenoid quinone detected in strains IMCC $35004^{\mathrm{T}}$ and IMCC $35005^{\mathrm{T}}$ is menaquinone-5 (MK-5), whereas those of the genera Desulfopila and Desulfotalea are MK-8 and MK-6, respectively (Table 1), suggesting that the two strains may belong to a novel genus from the family Desulfobulbaceae. 


\begin{tabular}{|c|c|c|c|c|c|c|c|}
\hline Characteristics & 1 & 2 & $3(n=2)$ & $4(n=2)$ & $5(n=2)$ & $6(n=3)$ & $7(n=1)$ \\
\hline Cell shape & $\mathrm{R}$ & $\mathrm{R}$ & $\mathrm{R}$ & $\mathrm{R}$ & $\mathrm{R}$ & $\mathrm{R}$ & $\mathrm{R}$ \\
\hline Motility by flagella & - & + & + & $\mathrm{v}$ & - & + & + \\
\hline Oxidase & - & - & - & - & $-{ }^{\mathrm{a}}$ & ND & ND \\
\hline Catalase & + & + & + & + & $t^{\mathrm{a}}$ & ND & ND \\
\hline $\begin{array}{l}\text { Utilization of } \\
\text { acetate }\end{array}$ & + & + & - & - & - & ND & - \\
\hline Sulfite reduction & + & + & + & $\mathrm{v}$ & + & + & + \\
\hline $\begin{array}{l}\text { Elemental sulfur } \\
\text { reduction }\end{array}$ & + & + & ND & - & - & + & + \\
\hline $\begin{array}{l}\mathrm{Fe}(\mathrm{III}) \text { citrate } \\
\text { reduction }\end{array}$ & + & + & + & + & ND & + & ND \\
\hline Quinone & MK-5 & MK-5 & MK-8 $\left(\mathrm{H}_{4}\right)$ & MK-6 $\left(\mathrm{H}_{2}\right)$ & MK-5 $\left(\mathrm{H}_{2}\right)$ & ND & MK-5 \\
\hline \multicolumn{8}{|l|}{\begin{tabular}{|l|} 
Ranges for growth \\
\end{tabular}} \\
\hline Temperature $\left({ }^{\circ} \mathrm{C}\right)$ & $15-30$ & $15-30$ & $10-40$ & $-1.8-30$ & $0-35$ & $20-30$ & $15-37$ \\
\hline $\mathrm{pH}$ & $6-9$ & $6-8.5$ & $7-9$ & $6.5-9.5$ & $5.7-8.2$ & $6.8-8.0$ & $6.7-8.3$ \\
\hline $\mathrm{NaCl}(\%)$ & $1-6$ & $2-5$ & $1-9$ & $1.5-5$ & $0.5-5$ & $1-1.5$ & ND \\
\hline Major polar lipids & PE, PG, DPG & PE, PG & PE, PG & PE, PG, DPG & ND & ND & ND \\
\hline $\begin{array}{l}\text { Major fatty acids } \\
(>10 \%)\end{array}$ & $\begin{array}{l}\mathrm{C}_{17: 1} \omega 6 c, \mathrm{C}_{16: 0}, \\
\mathrm{C}_{16: 1} \omega 5 c\end{array}$ & $\begin{array}{l}\mathrm{C}_{17: 1} \omega 6 c, \mathrm{C}_{16: 0} \\
\text { SF3, } \mathrm{C}_{16: 1} \omega 5 c \\
\end{array}$ & \begin{tabular}{|l|}
$\mathrm{C}_{16: 0}, \mathrm{C}_{16: 1} \omega 5 c$, \\
$\mathrm{C}_{17: 1} \omega 6 c$ \\
\end{tabular} & SF3, $C_{16: 0}, C_{14: 0}$ & $\begin{array}{l}\mathrm{C}_{15: 1} \omega 9 c, \mathrm{C}_{17: 1} \\
\omega 8 c,\end{array}$ & ND & ND \\
\hline Genome size $(\mathrm{Mb})$ & 5.7 & 6.8 & 6.1 & 3.5 & 5.0 & 4.0 & 5.0 \\
\hline $\begin{array}{l}\text { Genomic G+C } \\
\text { content }(\%)^{\mathrm{a}}\end{array}$ & 48.9 & 44.3 & $49.6,50.3^{\mathrm{b}}$ & 46.8 & 50.6 & 45.4 & 56.3 \\
\hline
\end{tabular}

Table 1. Characteristics that differentiate strains IMCC $35004^{\mathrm{T}}$ and IMCC $35005^{\mathrm{T}}$ from all the genera of the family Desulfocapsaceae. Strains: 1, IMCC $35004^{\mathrm{T}}$; 2, IMCC $35005^{\mathrm{T}}$; 3, Desulfopila ${ }^{16,29}$; this study $;$ 4, Desulfotalea ${ }^{15}$; this study; 5 , Desulforhopalus ${ }^{14,30} ; 6$, Desulfocapsa ${ }^{13,31} ; 7$, Desulfofustis ${ }^{12}$. n, number of species; +, positive; -, negative; v, variable; R, rod; ND, no data; PE, phosphatidylethanolamine; PG, phosphatidylglycerol; DPG, diphosphatidylglycerol; and SF3, summed feature $3\left(\mathrm{C}_{16: 1} \omega 7 c\right.$ and/or $\left.\mathrm{C}_{16: 1} \omega 6 c\right)$. ${ }^{\mathrm{a}}$ Values calculated from the genomic data unless otherwise indicated. ${ }^{b}$ Value calculated using high-performance liquid chromatography.

Bacterial community structure of the tidal-flat sediment. The bacterial community of the tidalflat sediment sample from which strains IMCC $35004^{\mathrm{T}}$ and IMCC $35005^{\mathrm{T}}$ were isolated was analyzed using $16 \mathrm{~S}$ rRNA gene amplicon sequencing. Classification of the resulting total of 113,202 reads showed that the tidal-flat sediment sample harbored diverse bacterial taxa (Fig. 4). At the phylum/class level, the phylum Desulfobacterota (28.4\%; $16 \mathrm{~S}$ rRNA gene sequence abundance) and the class Gammaproteobacteria (16.8\%) were identified to be the predominant bacteria, followed by the phyla Chloroflexi $(11.5 \%)$ and Bacteroidetes (10.7\%). This bacterial community structure is similar to those previously reported for tidal-flat sediments ${ }^{20,35}$. The most abundant family detected from the phylum Desulfobacterota was Desulfobacteraceae (11.4\%), followed by the families Desulfobulbaceae (6.0\%), Syntrophobacteraceae (1.5\%), and Desulfocapsaceae (0.7\%), indicating that SRB were enriched in the sampling area. To determine the relative abundance of the bacterial phylotypes related to strains IMCC $35004^{\mathrm{T}}$ and IMCC $35005^{\mathrm{T}}$, the number of $16 \mathrm{~S}$ rRNA gene amplicon sequences showing $\geq 98.7 \%$ sequence similarity to those of the isolates were determined using local BLAST search. The numbers of the amplicon sequences corresponding to the phylotypes related to IMCC $35004^{\mathrm{T}}$ and IMCC $35005^{\mathrm{T}}$ were $519(0.46 \%$ of total $)$ and $538(0.48 \%)$, respectively, indicating that the isolate-related phylotypes in the tidal flat constitute a minor portion of the bacterial community.

Taxonomic conclusion. Low 16S rRNA gene sequence similarity, low values of ANI and dDDH, and distinct phenotypic differences between strains IMCC $35004^{\mathrm{T}}$ and IMCC $35005^{\mathrm{T}}$ indicated that the two strains represent two independent species. However, inconsistencies in the phylogenetic positions of the two strains between the phylogenetic tree based on the 16S rRNA genes and that based on the whole genomes makes it difficult to assign the two strains into specific genera. Based on the AAI and POCP values between the two strains and the genera Desulfopila and Desulfotalea, the two strains might marginally belong to the genus Desulfopila or a novel genus, but formation of a robust phylogenetic clade and the difference in respiratory quinone content justify the classification of the two strains into a novel genus. Since physiological, genomic, and chemotaxonomic analyses showed that the two strains are novel sulfate-reducing bacteria distinct from the other type species in the family Desulfocapsaceae, the names Desulfosediminicola ganghwensis gen. nov., sp. nov. and Desulfosediminicola flagellatus sp. nov. are proposed, with IMCC $35004^{\mathrm{T}}$ and IMCC $35005^{\mathrm{T}}$ as the type strains, respectively.

Description of Desulfosediminicola gen. nov.. Desulfosediminicola (De.sul.fo.se.di.mi.ni'co.la. L. pref. de from; L. neut. n. sulfur sulfur; L. neut. n. sedimen sediment; L. masc. suff. -cola (from L. masc. n. incola) an inhabitant; N.L. masc. n. Desulfosediminicola sulfate reducing sediment dweller).

Gram-stain-negative, sulfate-reducing, strictly anaerobic, and chemoheterotrophic. Rod-shaped. Oxidasenegative and catalase-positive. Sulfate, sulfite, elemental sulfur, thiosulfate, Fe(III) citrate, and $\mathrm{Mn}$ (IV) oxide are 


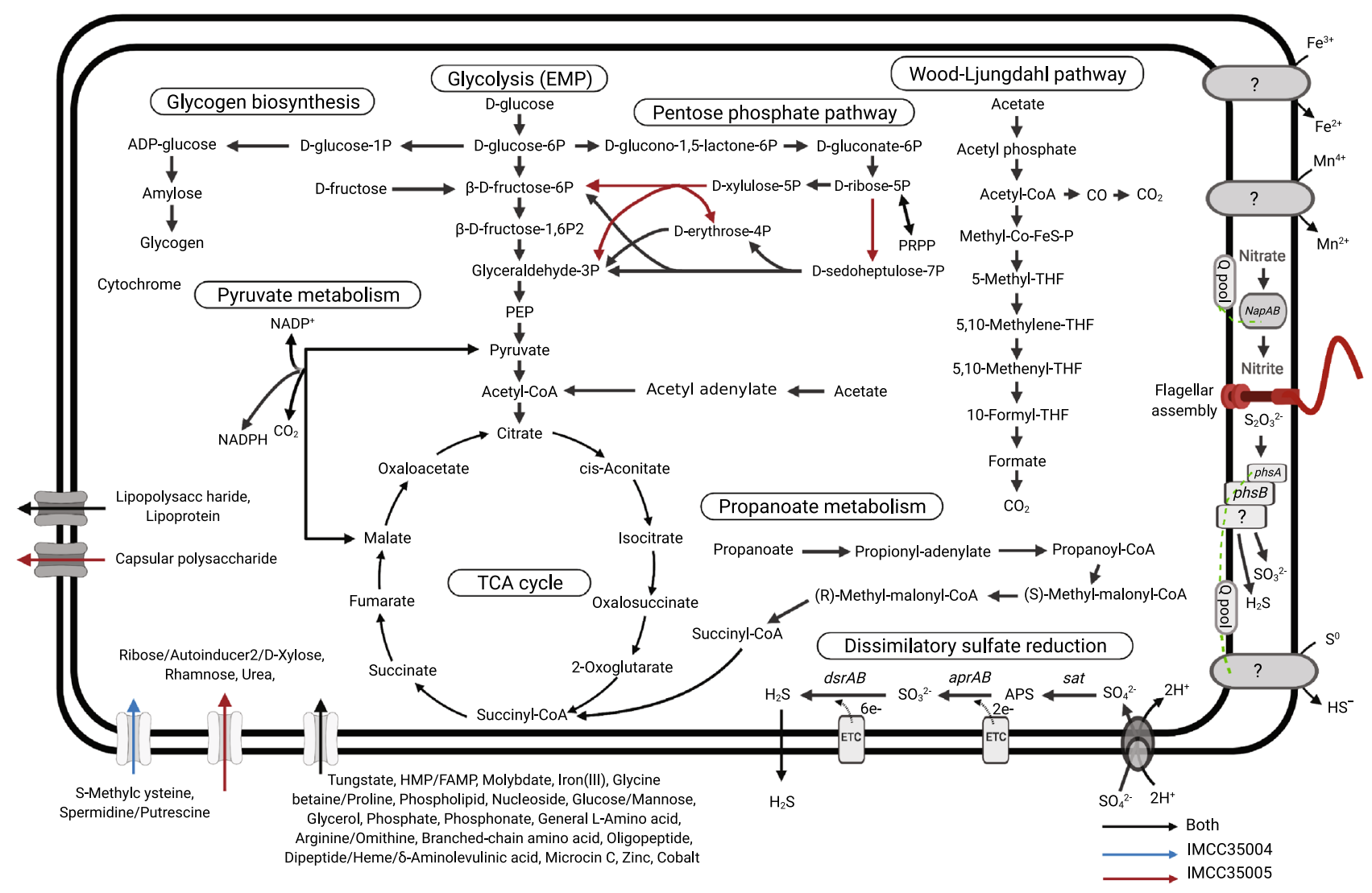

Figure 3. Overview of the metabolic pathways in strains IMCC $35004^{\mathrm{T}}$ and $\mathrm{IMCC} 35005^{\mathrm{T}}$. The presence and absence of genes were predicted based on the annotations from Kyoto Encyclopedia of Genes and Genomes. Genes predicted to be present in the phenotypic characterization but not found in the genome sequences are marked with question marks. Created with BioRender.com.

reduced as electron acceptors. Requires $\mathrm{NaCl}$ for growth. The major fatty acids are $\mathrm{C}_{17: 1} \omega 6 c, \mathrm{C}_{16: 0}$, and $\mathrm{C}_{16: 1} \omega 5 c$. The major quinone is MK-5. The major polar lipids identified are PE and PG. Belongs to the family Desulfocapsaceae. The type species is Desulfosediminicola ganghwensis.

Description of Desulfosediminicola ganghwensis sp. nov.. Desulfosediminicola ganghwensis (gang. hwen'sis. N.L. masc. adj. ganghwensis pertaining to Ganghwa Island, Republic of Korea, the geographical origin of the type strain of the species).

Gram-stain-negative, strictly anaerobic, and rod-shaped with a width of $0.7-0.9 \mu \mathrm{m}$ and length of $2.2-2.6 \mu \mathrm{m}$. The colonies are $0.4-0.7 \mathrm{~mm}$ in diameter, beige-colored, smooth, convex, and circular with an entire margin after 3 weeks of incubation on $3 \mathrm{M}-\mathrm{R} 2 \mathrm{~A}$ at $25^{\circ} \mathrm{C}$. Black colonies emerge on MA. Requires vitamins for growth. Growth occurs at $15-30^{\circ} \mathrm{C}$ (optimum, $25^{\circ} \mathrm{C}$ ) and $\mathrm{pH}$ 6.5-9.0 (optimum, $\mathrm{pH} 7.0$ ) with 1.0-6.0\% $\mathrm{NaCl}$ (optimum, 3.0\%). Tween 20 and Tween 80 are hydrolyzed, but starch, CM-cellulose, chitin, casein, or DNA is not hydrolyzed. Sulfate, sulfite, elemental sulfur, thiosulfate, $\mathrm{Fe}$ (III) citrate, and $\mathrm{Mn}$ (IV) oxide are used as electron acceptors, but $\mathrm{Fe}(\mathrm{III})$ oxyhydroxide, nitrate, or nitrite is not reduced. No autotrophic growth based on thiosulfate disproportionation or hydrogen oxidation is observed. $\mathrm{H}_{2} \mathrm{~S}$ is produced. $\alpha$-Ketoglutarate, acetate, alanine, betaine, ethanol, fumarate, glycine, and malate are used as electron donors, but benzoate, butanol, butyrate, choline chloride, glutamate, glycerol, lactate, mannitol, methanol, propanol, propionate, serine, or succinate is not utilized. In API $20 \mathrm{~A}$, acid is produced from salicin, D-xylose, glycerol, D-mannose, and D-melezitose but not from D-glucose, D-mannitol, D-lactose, D-saccharose, D-maltose, L-arabinose, D-cellobiose, D-raffinose, D-sorbitol, L-rhamnose, or D-trehalose. Hydrolysis of esculin is positive, but gelatin liquefaction is negative. Indole formation and urease are undetected. In API ZYM, alkaline phosphatase, esterase (C4), esterase lipase (C8), acid phosphatase, and naphthol-AS-BI-phosphohydrolase were detected, but lipase (C14), leucine arylamidase, valine arylamidase, cystine arylamidase, trypsin, $\alpha$-chymotrypsin, $\alpha$-galactosidase, $\beta$-galactosidase, $\beta$-glucuronidase, $\alpha$-glucosidase, $\beta$-glucosidase, $N$-acetyl- $\beta$-glucosaminidase, $\alpha$-mannosidase, or $\alpha$-fucosidase was undetected. The respiratory quinone is MK-5. The major fatty acids are $\mathrm{C}_{17: 1} \omega 6 c, \mathrm{C}_{16: 0}$ and $\mathrm{C}_{16: 1} \omega 5 c$. The major polar lipids are PE, PG, and DPG, an unidentified aminophospholipid, two unidentified aminolipids, four unidentified phospholipids, and four unidentified lipids. The type strain IMCC $35004^{\mathrm{T}}\left(=\right.$ KCTC $\left.15826^{\mathrm{T}}=\mathrm{NBRC} 114003^{\mathrm{T}}\right)$ was isolated from the tidal-flat sediment of Ganghwa Island, Republic of Korea. The whole-genome of the type strain is $5.7 \mathrm{Mb}$. The genomic $\mathrm{G}+\mathrm{C}$ content of the type strain is $48.9 \mathrm{~mol} \%$. The GenBank accession numbers of the $16 \mathrm{~S}$ rRNA gene sequences and the complete genome sequence of the type strain are MK660563 and CP05699, respectively. 


\begin{tabular}{|c|c|c|c|c|}
\hline Characteristics & 1 & 2 & 3 & 4 \\
\hline Cell size (width $\times$ length, $\mu \mathrm{m}$ ) & $0.7-0.9 \times 2.2-2.6$ & $0.9-1.1 \times 1.5-2.2$ & $0.7-1.2 \times 1.9-3.8^{\mathrm{a}}$ & $0.6 \times 4.5-7.4^{\mathrm{b}}$ \\
\hline Presence of flagella & - & + & + & + \\
\hline \multicolumn{5}{|l|}{ Growth range (optimum) } \\
\hline Temperature $\left({ }^{\circ} \mathrm{C}\right)$ & $15-30(25)$ & $15-30(25)$ & $10-40(30)$ & $\begin{array}{l}4-18(15) \\
-1.8-19(10)^{b}\end{array}$ \\
\hline $\mathrm{NaCl}(\%)$ & $1-6(3)$ & $2-5(2)$ & $\begin{array}{l}1-5(1) \\
0-5(1)^{\mathrm{a}}\end{array}$ & $\begin{array}{l}1-6(1) \\
1.5-2.5(1)^{b}\end{array}$ \\
\hline $\mathrm{pH}$ & $6.5-9(7)$ & 6-8.5 (7) & \begin{tabular}{|l|}
$6.5-8.5(7.5)$ \\
$6.3-8.5(7.5-7.6)^{\mathrm{a}}$
\end{tabular} & $\begin{array}{l}6-8(7) \\
\text { ND }(7.3-7.6)^{b}\end{array}$ \\
\hline \multicolumn{5}{|l|}{ Electron acceptors } \\
\hline Nitrate & - & - & + & - \\
\hline Fe(III) oxyhydroxide & - & + & + & - \\
\hline \multicolumn{5}{|l|}{ Electron donors $^{\mathrm{c}}$} \\
\hline Acetate & + & + & - & - \\
\hline$\alpha$-Ketoglutarate, alanine, betaine, ethanol, glycine, malate & + & - & - & - \\
\hline Benzoate & - & - & + & - \\
\hline Butanol, propanol, glycerol, succinate & - & + & - & - \\
\hline Choline chloride, serine, mannitol & - & - & + & - \\
\hline Glutamate, lactate & - & - & + & + \\
\hline Propionate & - & - & - & + \\
\hline \multicolumn{5}{|l|}{ API ZYM } \\
\hline Esterase lipase (C8) & + & + & - & + \\
\hline Leucine arylamidase & - & + & + & + \\
\hline Valine arylamidase, $\beta$-galactosidase & - & - & - & + \\
\hline$\beta$-Glucuronidase & - & + & - & + \\
\hline$\alpha$-Glucosidase & - & + & - & - \\
\hline \multicolumn{5}{|l|}{ Hydrolysis } \\
\hline Tween 20 & + & - & + & - \\
\hline Tween 80 & + & - & - & - \\
\hline
\end{tabular}

Table 2. Differential phenotypic characteristics of IMCC $35004^{\mathrm{T}}$, IMCC $35005^{\mathrm{T}}$, and the type strains of the related genera. Strains: 1, IMCC $35004^{\mathrm{T}}$; 2, IMCC $35005^{\mathrm{T}} ; 3$, Desulfopila aestuarii DSM $18488^{\mathrm{T}}$; 4, Desulfotalea psychrophila DSM $12343^{\mathrm{T}}$. All the data are from this study unless otherwise indicated. All the strains are positive for reduction of sulfate, sulfite, thiosulfate, $\mathrm{Fe}(\mathrm{III})$ citrate and $\mathrm{Mn}(\mathrm{IV})$ oxide; production of $\mathrm{H}_{2} \mathrm{~S}$; catalase; utilization fumarate; alkaline phosphatase, esterase (C4), trypsin, acid phosphatase, and naphthol-ASBI-phosphohydrolase. All the strains are negative for reduction of nitrite; utilization of butyrate or methanol; oxidase; lipase (C14); cystine arylamidase; $\alpha$-chymotrypsin; $\alpha$-galactosidase; $\beta$-glucosidase; $N$-acetyl- $\beta$ glucosaminidase; $\alpha$-mannosidase; $\alpha$-fucosidase; and hydrolysis of DNA, casein, CM-cellulose, and chitin. + , positive; -, negative, ND; no data. ${ }^{a}$ Data from Suzuki et al. ${ }^{16}$. ${ }^{b}$ Data from Knoblauch et al. ${ }^{15}$. ${ }^{\mathrm{C}}$ Ethanol, butanol, and propanol were adjusted to $0.02 \%$, benzoate was adjusted to $5 \mathrm{mM}$ and other carbons to $20 \mathrm{mM}$.

Description of Desulfosediminicola flagellatus sp. nov.. Desulfosediminicola flagellatus (fla.gel.la'tus. L. part. adj. flagellatus flagellated).

The cells are Gram-stain-negative, strictly anaerobic, motile by a single polar flagellum, and rod-shaped with a width of $0.9-1.1 \mu \mathrm{m}$ and length of 1.5-2.2 $\mu \mathrm{m}$. The colonies are $0.4-0.7 \mathrm{~mm}$ in diameter, beige-colored, smooth, convex, and circular with an entire margin after 3 weeks of incubation on $3 \mathrm{M}-\mathrm{R} 2 \mathrm{~A}$ at $25^{\circ} \mathrm{C}$. Black colonies emerge on MA. Requires vitamins for growth. Growth occurs at $15-30{ }^{\circ} \mathrm{C}$ (optimum, $25^{\circ} \mathrm{C}$ ) and pH $6.0-8.5$ (optimum, pH 7.0) with 2.0-5.0\% NaCl (optimum, 2.0\%). Starch, CM-cellulose, chitin, casein, Tween 20, Tween 80 , or DNA is not hydrolyzed. Sulfate, sulfite, elemental sulfur, thiosulfate, $\mathrm{Fe}$ (III) citrate, $\mathrm{Fe}$ (III) oxyhydroxide, and $\mathrm{Mn}(\mathrm{IV})$ oxide are used as electron acceptors, but nitrate or nitrite is not reduced. No autotrophic growth based on thiosulfate disproportionation or hydrogen oxidation is observed. $\mathrm{H}_{2} \mathrm{~S}$ is produced. Acetate, butanol, fumarate, glycerol, propanol, and succinate are used as electron donors, but $\alpha$-ketoglutarate, alanine, benzoate, betaine, butyrate, choline chloride, ethanol, glutamate, glycine, lactate, malate, mannitol, methanol, propionate, or serine is not utilized. In API 20A, acid is produced from D-glucose, D-mannitol, D-saccharose, D-maltose, salicin, L-arabinose, esculin, glycerol, D-cellobiose, D-sorbitol, or D-trehalose but not from D-lactose, D-xylose, D-mannose, D-melezitose, D-raffinose, or L-rhamnose. Hydrolysis of esculin is positive, but gelatin liquefaction is negative. Indole formation and urease are undetected. In API ZYM, alkaline phosphatase, esterase (C4), esterase lipase (C8), leucine arylamidase, acid phosphatase, naphthol-AS-BI-phosphohydrolase, $\beta$-glucuronidase, and $\alpha$-glucosidase are detected, but lipase (C14), valine arylamidase, cystine arylamidase, trypsin, $\alpha$-chymotrypsin, $\alpha$-galactosidase, $\beta$-galactosidase, $\beta$-glucosidase, $N$-acetyl- $\beta$-glucosaminidase, $\alpha$-mannosidase, or $\alpha$-fucosidase is not. The predominant respiratory quinone is $\mathrm{MK}-5$. The major fatty acids are $\mathrm{C}_{17: 1} \omega 6 c, \mathrm{C}_{16: 0}$, summed feature 


\begin{tabular}{|c|c|c|c|c|}
\hline Fatty acids (\%) & 1 & 2 & 3 & 4 \\
\hline \multicolumn{5}{|l|}{ Saturated } \\
\hline $\mathrm{C}_{14: 0}$ & 4.3 & 1.4 & 1.6 & 14.3 \\
\hline $\mathrm{C}_{16: 0}$ & 17.6 & 21.6 & 28.8 & 17.7 \\
\hline $\mathrm{C}_{17: 0}$ & 1.6 & 6.0 & 4.7 & - \\
\hline $\mathrm{C}_{18: 0}$ & 6.0 & $\operatorname{Tr}$ & $\operatorname{Tr}$ & $\operatorname{Tr}$ \\
\hline \multicolumn{5}{|l|}{ Unsaturated } \\
\hline $\mathrm{C}_{14: 1} \omega 5 c$ & - & - & $\operatorname{Tr}$ & 2.7 \\
\hline $\mathrm{C}_{15: 1} \omega 6 c$ & - & 4.0 & 4.0 & 2.9 \\
\hline $\mathrm{C}_{16: 1} \omega 9 c$ & 1.1 & $\operatorname{Tr}$ & - & - \\
\hline $\mathrm{C}_{16: 1} \omega 5 c$ & 11.2 & 12.3 & 20.9 & 9.2 \\
\hline $\mathrm{C}_{17: 1} \omega 8 c$ & 3.0 & 1.7 & - & - \\
\hline $\mathrm{C}_{17: 1} \omega 6 c$ & 21.6 & 23.4 & 16.7 & $\operatorname{Tr}$ \\
\hline $\mathrm{C}_{18: 1} \omega 9 c$ & 3.6 & $\mathrm{Tr}$ & - & 3.2 \\
\hline $\mathrm{C}_{18: 1} \omega 5 c$ & 2.4 & $\operatorname{Tr}$ & $\operatorname{Tr}$ & - \\
\hline Methyl $\mathrm{C}_{18: 1} \omega 7 c$ & 1.2 & $\operatorname{Tr}$ & $\operatorname{Tr}$ & - \\
\hline \multicolumn{5}{|l|}{ Branched } \\
\hline iso- $\mathrm{C}_{14: 0}$ & 2.0 & - & - & - \\
\hline iso- $\mathrm{C}_{15: 0}$ & 1.6 & 1.9 & $\operatorname{Tr}$ & $\operatorname{Tr}$ \\
\hline anteiso- $\mathrm{C}_{15: 0}$ & 2.8 & $\operatorname{Tr}$ & - & - \\
\hline iso- $\mathrm{C}_{16: 0} \mathrm{H}$ & $\operatorname{Tr}$ & $\mathrm{Tr}$ & 4.0 & - \\
\hline iso- $\mathrm{C}_{16: 0}$ & $\operatorname{Tr}$ & - & 1.8 & - \\
\hline iso- $\mathrm{C}_{17: 0}$ & $\operatorname{Tr}$ & 2.4 & $\operatorname{Tr}$ & - \\
\hline \multicolumn{5}{|l|}{ Summed features $^{\mathrm{a}}$} \\
\hline 3 & 6.1 & 16.3 & 12.6 & 44.3 \\
\hline 4 & - & 2.6 & 1.1 & - \\
\hline 5 & - & $\operatorname{Tr}$ & - & 1.2 \\
\hline 8 & 9.8 & $\operatorname{Tr}$ & $\operatorname{Tr}$ & $\operatorname{Tr}$ \\
\hline 9 & - & 1.8 & $\operatorname{Tr}$ & - \\
\hline
\end{tabular}

Table 3. Cellular fatty acid compositions of IMCC $35004^{\mathrm{T}}$, IMCC $35005^{\mathrm{T}}$, and the type strains of the related genera. Strains: 1, IMCC $35004^{\mathrm{T}}$; 2, IMCC $35005^{\mathrm{T}}$; 3, Desulfopila aestuarii DSM 18488 ${ }^{\mathrm{T}}$; 4, Desulfotalea psychrophila DSM $12343^{\mathrm{T}}$. All the data are from this study. - , Not detected; Tr, traces $(<1.0 \%)$. Major fatty

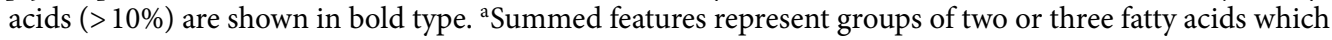
could not be separated using gas chromatography with the MIDI system. Summed feature 3 comprises $\mathrm{C}_{16: 1}$ $\omega 7 c$ and/or $\mathrm{C}_{16: 1} \omega 6 c$; Summed feature 4 comprises anteiso- $\mathrm{C}_{17: 1} \mathrm{~B}$ and/or iso- $\mathrm{C}_{17: 1} \mathrm{I}$; Summed feature 5 comprises $\mathrm{C}_{18: 2} \omega 6,9 c$ and/or anteiso- $\mathrm{C}_{18: 0}$; Summed feature 8 comprises $\mathrm{C}_{18: 1} \omega 7 c$ and/or $\mathrm{C}_{18: 1} \omega 6 c$; Summed feature 9 comprises 10 -methyl $\mathrm{C}_{16: 0}$ and/or iso- $\mathrm{C}_{17: 1} \omega 9 c$.

$3\left(\mathrm{C}_{16: 1} \omega 7 c\right.$ and/or $\left.\mathrm{C}_{16: 1} \omega 6 c\right)$, and $\mathrm{C}_{16: 1} \omega 5 c$. The major polar lipids are phosphatidylethanolamine, phosphatidylglycerol, an unidentified aminolipid, and five unidentified lipids. The type strain IMCC $35005^{\mathrm{T}}$ (= KCTC $15827^{\mathrm{T}}=$ NBRC $114004^{\mathrm{T}}$ ) was isolated from the tidal-flat sediment of Ganghwa Island, Republic of Korea. The whole-genome of the type strain is $6.8 \mathrm{Mb}$. The genomic $\mathrm{G}+\mathrm{C}$ content of the type strain is $44.3 \mathrm{~mol} \%$. The GenBank accession numbers of the $16 \mathrm{~S}$ rRNA gene sequence and the complete genome sequence of the type strain are MK660564 and CP05698, respectively.

\section{Materials and methods}

Isolation and culture conditions. A sediment sample was collected off the coast of Ganghwa Island ( $37^{\circ}$ $35^{\prime} 26^{\prime \prime} \mathrm{N}, 126^{\circ} 27^{\prime} 17^{\prime \prime} \mathrm{E}$ ), South Korea, in July 2018 using a $30 \mathrm{~cm}$ long acrylic core sampler with a $10 \mathrm{~cm}$ diameter. The sediment core was sealed in an anaerobic bag, transported to the laboratory in an ice cooler, and then transferred into a vinyl anaerobic chamber (Coy Laboratory Products) filled with $\mathrm{N}_{2}: \mathrm{H}_{2}: \mathrm{CO}_{2}$ (90:5:5). A sub-sample $(1 \mathrm{~g})$ was collected from the middle of the sediment core and homogenized with $10 \mathrm{ml}$ of sterile aged seawater. For long-term storage, $500 \mu \mathrm{l}$ of the diluted homogenized sample in $10 \%(\mathrm{v} / \mathrm{v})$ glycerol solution was stored at $-80^{\circ} \mathrm{C}$. An aliquot $(100 \mu \mathrm{l})$ of the diluted homogenized sediment sample was spread onto marine agar 2216 (MA; BD Diagnostics) and anaerobically incubated in an anaerobic jar (Mitsubishi Gas Chemical) at $17^{\circ} \mathrm{C}$. After incubation for 3 weeks, two black-colored colonies that appeared on the MA plates were picked and sub-cultured three times. After 16S RNA gene sequencing, the two strains were designated as IMCC $35004^{\mathrm{T}}$ and IMCC $35005^{\mathrm{T}}$. After the optimum culture conditions had been determined, the two strains were routinely maintained on MA or 3M-R2A ( $0.5 \mathrm{~g}$ yeast extract, $0.5 \mathrm{~g}$ casamino acid, $0.5 \mathrm{~g}$ proteose peptone no.3, $0.5 \mathrm{~g}$ glucose, $0.5 \mathrm{~g}$ soluble starch, $0.3 \mathrm{~g}$ sodium pyruvate, and $15 \mathrm{~g}$ agar in $1 \mathrm{~L}$ of $80 \%$ aged seawater) at $25^{\circ} \mathrm{C}$ under anaerobic conditions. The cultures were stored at $-80^{\circ} \mathrm{C}$ as $10 \%(\mathrm{v} / \mathrm{v})$ glycerol suspensions. For physiological and chemo- 
(A)

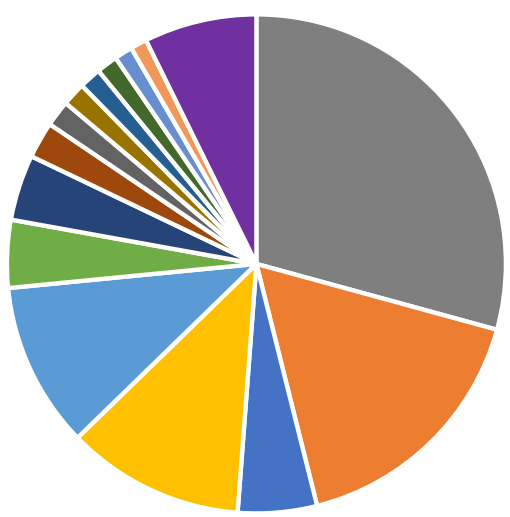

- Desulfobacterota

- Chloroflexi

- Planctomycetes

- Epsilonbacteraeota

- Calditrichaeota
- Gammaproteobacteria - Alphaproteobacteria - Bacteroidetes

- Latescibacteria

- Verrucomicrobia

- Firmicutes
- Acidobacteria

- Actinobacteria

- Gemmatimonadetes

- Other
(B)

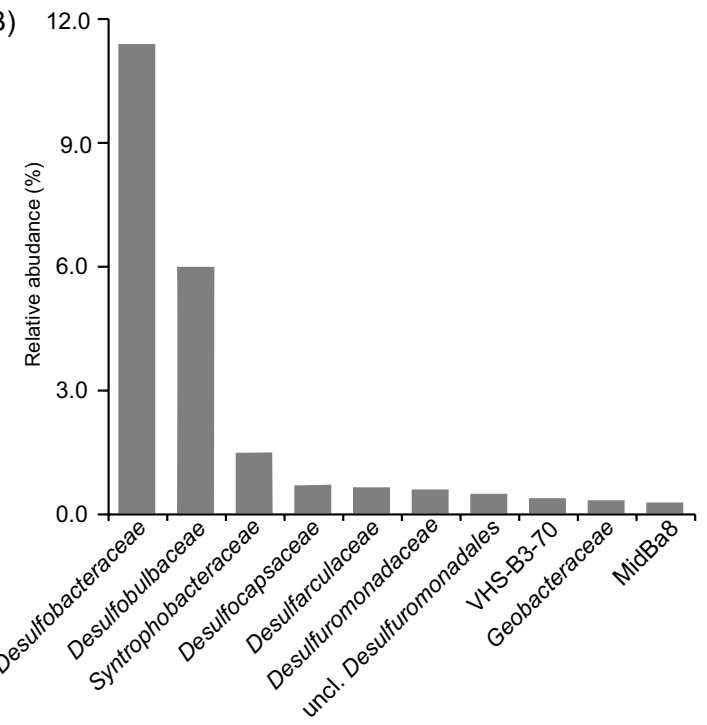

Figure 4. Relative abundance of bacterial taxa at the phylum/class level (a) and the 10 most abundant families from the phylum Desulfobacterota (b).

taxonomic comparisons, the type species Desulfopila aestuarii DSM $18488^{\mathrm{T}}$ and Desulfotalea psychrophila DSM $12343^{\mathrm{T}}$ were obtained from the Deutsche Sammlung von Mikroorganismen und Zellkulturen GmbH (DSMZ). Desulfopila aestuarii DSM $18488^{\mathrm{T}}$ and Desulfotalea psychrophila DSM $12343^{\mathrm{T}}$ were routinely cultivated at $25^{\circ} \mathrm{C}$ and $15{ }^{\circ} \mathrm{C}$, respectively, on MA or $3 \mathrm{M}-\mathrm{R} 2 \mathrm{~A}$ under anaerobic conditions. Unless otherwise indicated, all the media used in this study were autoclaved in a Duran bottle equipped with a rubber stopper, after sparging with $\mathrm{N}_{2}$ gas for 20 min per $1 \mathrm{~L}$ medium.

Phylogenetic analyses based on 16S rRNA gene sequences. The genomic DNAs of strains IMCC $35004^{\mathrm{T}}$ and IMCC $35005^{\mathrm{T}}$ were extracted using DNeasy Blood and Tissue kit (Qiagen) according to the manufacturer's instructions. The 16S rRNA genes of the strains were amplified using PCR with the bacterial universal primers $27 \mathrm{~F}$ and $1492 \mathrm{R}^{36}$ and sequenced using a Sanger sequencer. The resultant almost complete $16 \mathrm{~S}$ rRNA gene sequences of strains IMCC $35004^{\mathrm{T}}(1469 \mathrm{bp})$ and $\mathrm{IMCC}^{\mathrm{T}} 3005^{\mathrm{T}}(1470 \mathrm{bp})$ were identified using BLASTn at GenBank and the "16S-based ID service" in the EzBioCloud database ${ }^{17}$. For phylogenetic analyses, the 16S rRNA gene sequences of the two strains were aligned using the SILVA Incremental Aligner ${ }^{37}$ and imported into the ARB database ${ }^{38}$. The aligned and manually curated $16 \mathrm{~S}$ rRNA gene sequences in the ARB database were exported to the MEGA X program ${ }^{39}$, which was then used for constructing phylogenetic trees based on the neighbor-joining ${ }^{40}$, maximum-likelihood ${ }^{41}$, and minimum-evolution ${ }^{42}$ methods with Jukes-Cantor parameter, the Tamura-Nei model, and Jukes-Cantor correction, respectively. The robustness of the phylogenetic trees was evaluated using bootstrap analyses based on 1000 random re-samplings ${ }^{43}$.

Sequencing of the 165 rRNA gene amplicons derived from the tidal-flat sediment sample. For $16 \mathrm{~S}$ rRNA gene amplicon sequencing of the sediment sample, the diluted homogenized sample stored at $-80^{\circ} \mathrm{C}$ was thawed and subsequently centrifuged at $10,000 \mathrm{~g}$ for $1 \mathrm{~h}$. After the supernatant was removed, DNA was extracted from the sediment pellet by using the DNeasy PowerSoil Kit (Qiagen) following the manufacturer's instructions. The quantity and quality of the DNA were measured using Qubit 3.0 (ThermoFisher Scientific) and Nanodrop (ThermoFisher Scientific). The V4 region of the 16S rRNA gene was amplified using fusion primers that were designed based on the universal primers 515F-Y and 806R-B ${ }^{44}$. Amplicon sequencing of pooled PCR products was performed using an Illumina MiSeq System $(2 \times 250 \mathrm{bp})$ at ChunLab, Inc. (Korea). The raw amplicon sequencing data were processed using the Quantitative Insights into Microbial Ecology Version 2 (QIIME2, version 2019.10. $)^{45}$. Primer sequences were removed using Cutadapt ${ }^{46}$, and DADA2 plugin was used for quality-filtering, read-joining, chimera removal, and denoising ${ }^{47}$. The amplicon sequence variants (ASVs) obtained using DADA2 were classified using the "feature-classifier" command (with the "classify-sklearn" option) and a classifier pre-trained based on Silva 138 release ("silva-138-99-515-806-nb-classifier.qza").

Whole-genome sequencing and genomic analyses. Whole-genome sequencing of strains

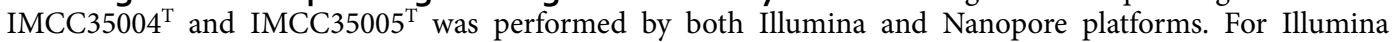
sequencing, the genomic DNAs of strains IMCC $35004^{\mathrm{T}}$ and $\mathrm{IMCC} 35005^{\mathrm{T}}$ were extracted using DNeasy Blood and Tissue kit (Qiagen) according to the manufacturer's instructions. DNA library was constructed using the TruSeq Nano DNA Library Prep Kit (Illumina). Illumina sequencing was performed at ChunLab, Inc. (Korea) by using the MiSeq system with $2 \times 300 \mathrm{bp}$ paired-end run. For Nanopore genome sequencing, the genomic DNAs were extracted using the MagAttract HMW DNA Kit (Qiagen). Sequencing libraries were prepared using the Ligation Sequencing Kit (SQK-LSK109, Oxford Nanopore Technologies) and Native Barcoding Expansion 
pack (EXP-NBD104, Oxford Nanopore Technologies) and then loaded and sequenced using a flow cell (R9.4.1) on a MinION device (Oxford Nanopore Technologies). Guppy (v3.4.5) was used at the high-accuracy mode for the base-calling of the nanopore data. The hybrid assemblies of the both Illumina and Nanopore reads were performed using Unicycler version $0.4 .8^{48}$. The following Desulfocapsaceae genomes were downloaded from the GenBank for the genomic comparison: Desulfopila aestuarii DSM $18488^{\mathrm{T}}$ (FRFE00000000) and Desulfotalea psychrophila LSv54 ${ }^{\mathrm{T}}$ (CR522870). For calculating the genome relatedness among the Desulfocapsaceae genomes, the corresponding ANI and $\mathrm{dDDH}$ values were calculated using the JSpecies web server ${ }^{49}$ and genome-to-genome distance calculator (GGDC 2.1 $)^{50}$. The $\mathrm{AAI}^{51}$ and $\mathrm{POCP}^{27}$ were computed to measure the genomic similarity based on the amino-acid sequences. Phylogenomic tree was inferred using the up-to-date bacterial core gene (UBCG) pipeline, consisting of 92 genes, with the default parameters ${ }^{52}$.

For the reconstruction of metabolic pathways, each genome was annotated using Prokka ${ }^{53}$, and the resultant open reading frames were queried into BlastKOALA ${ }^{54}$ and KofamKOALA ${ }^{55}$ according to the Kyoto Encyclopedia of Genes and Genomes database. For the analysis of distribution of Clusters of Orthologous Groups (COG) categories, the protein sequences obtained using Prokka were queried against the COG database by using RPS-BLAST (e-value cutoff; 0.01) ${ }^{56}$. The orthogroups among the genome-encoded proteins were determined using OrthoFinder (version 2.3.11) with BLAST + as a sequence search program ${ }^{57}$, and the number of shared or unique orthologous protein clusters was depicted on a Venn diagram by using the package "venn" (version 1.9) in R environment.

Morphological, physiological, and biochemical characterization. As for phenotypic characterization, unless otherwise noted, cells grown on MA or in MB (marine broth 2216 ) at $25^{\circ} \mathrm{C}$ for 3 weeks under anaerobic conditions were used. Gram-staining was performed using a Gram-staining kit (bioMérieux). Cell morphology was examined using a transmission electron microscope (TEM; CM200, Philips). A TEM specimen was prepared using a carbon-coated copper grid (Electron Microscopy Sciences) holding the cells stained with 2\% (w/v) uranyl acetate. Motility by flagella was confirmed using the semi-solid R2A agar medium (0.5\%). Growth was measured at $4,10,15,20,25,30,37,42$, and $45^{\circ} \mathrm{C}$ in $\mathrm{MB}$. The $\mathrm{pH}$ range and optimal value for growth were monitored in $\mathrm{MB}$ adjusted to $\mathrm{pH} 5.0-10.0$ (at $1.0 \mathrm{pH}$ unit intervals) by using the following buffers: $1 \mathrm{M} \mathrm{MES}, 1 \mathrm{M}$ MOPS, 1 M HEPES, $1 \mathrm{M}$ Tris, and 0.5 M CHES buffers for $\mathrm{pH}$ 5.0-6.0, 7.0, 8.0, 9.0, and 10.0, respectively. The growth at various concentrations of $\mathrm{NaCl}(0-8.0 \%$ at increments of $1.0 \%)$ were determined by supplementing $\mathrm{NaCl}$ into $\mathrm{NaCl}$-free $\mathrm{MB}$. Catalase and oxidase activities were assessed using 3.0\% (v/v) hydrogen peroxide and the Kovac's solution (bioMérieux), respectively. The bacterial strains were tested for their abilities to hydrolyze the following macromolecules, which were added into 3M-R2A: casein (3.0\% skimmed milk, w/v), chitin ( $1.0 \%$, w/v), starch (1.0\%, w/v), CM-cellulose (1.0\% CM-cellulose, w/v), Tween $20(1.0 \%$, w/v), or Tween $80(1.0 \%$, w/v). DNase test agar (BD Diagnostics) supplemented with $2 \% \mathrm{NaCl}$ was used to assess for DNA-degradation activity. Production of $\mathrm{H}_{2} \mathrm{~S}$ was investigated using triple sugar iron agar (TSI; BD Diagnostics) with $2 \% \mathrm{NaCl}$.

The electron acceptors for the anaerobic respiration were evaluated in a modified artificial seawater (ASW) medium (19.45 g NaCl, $8.8 \mathrm{~g} \mathrm{MgCl}_{2}, 1.8 \mathrm{~g} \mathrm{CaCl}_{2}, 0.55 \mathrm{~g} \mathrm{KCl}, 0.16 \mathrm{~g} \mathrm{NaHCO}_{3}, 0.08 \mathrm{~g} \mathrm{KBr}, 0.034 \mathrm{~g} \mathrm{SrCl}_{2}, 0.022 \mathrm{~g}$ $\mathrm{H}_{3} \mathrm{BO}_{3}, 0.0024 \mathrm{~g} \mathrm{NaF}, 0.004 \mathrm{~g} \mathrm{Na}_{2} \mathrm{SiO}_{3}, 0.0016 \mathrm{~g} \mathrm{NH}_{4} \mathrm{NO}_{3}$, and $0.008 \mathrm{~g} \mathrm{Na}_{2} \mathrm{HPO}_{4}$ in $1 \mathrm{~L}$ deionized water) containing trace metals ${ }^{58}$ and a vitamin mixture ${ }^{59}$. The following electron acceptors were tested in the ASW medium supplemented with $20 \mathrm{mM}$ acetate as the electron donor: sulfate $\left(20 \mathrm{mM} \mathrm{Na}_{2} \mathrm{SO}_{4}\right)$, sulfite $\left(10 \mathrm{mM} \mathrm{Na}_{2} \mathrm{SO}_{3}\right)$, elemental sulfur (powder; $1 \mathrm{mM}$ ), thiosulfate $\left(10 \mathrm{mM} \mathrm{Na}_{2} \mathrm{~S}_{2} \mathrm{O}_{3}\right), \mathrm{Fe}$ (III) citrate $\left(5 \mathrm{mM} \mathrm{FeC}_{6} \mathrm{H}_{5} \mathrm{O}_{7}\right), \mathrm{Fe}$ (III) oxyhydroxide [5 mM Fe(OH) $\left.)_{3}\right], \mathrm{Mn}(\mathrm{IV})\left(345 \mu \mathrm{M} \mathrm{MnO}_{2}\right)$, nitrate $\left(3 \mathrm{mM} \mathrm{NaNO}_{3}\right)$, and nitrite $\left(484 \mu \mathrm{M} \mathrm{NaNO}_{2}\right)$. Cells $\left(10^{4}\right.$ cells/ $\mathrm{ml}$ ) were inoculated into $10 \mathrm{ml}$ ASW medium in a serum bottle and cultivated at $25^{\circ} \mathrm{C}$ for 3 weeks. The concentrations of sulfate, nitrate, and nitrite were determined using the SulfaVer 4 (Hach), cadmium-reduction (Hach), and ferrous-sulfate (Hach) methods, respectively, according to the manufacturer's instructions. Reduction of sulfite and elemental sulfur, $\mathrm{Fe}(\mathrm{III})$, and $\mathrm{Mn}(\mathrm{IV})$ was determined by measuring the concentrations of sulfide, $\mathrm{Fe}(\mathrm{II})$, and $\mathrm{Mn}$ (II) by using the methylene-blue method (Hach), 1,10-Phenanthroline Kit (Hach), and WAK-Mn test (Pack Test kits; Kyoritsu Chemical-Check Lab), respectively. Reduction of thiosulfate was determined based on the colorimetric method described previously ${ }^{60}$. To evaluate the electron donors, 19 sole-carbon sources at a final concentration of $20 \mathrm{mM}$ or $0.02 \%(\mathrm{v} / \mathrm{v})$, except for benzoate $(5 \mathrm{mM})$, were added into the ASW medium with $20 \mathrm{mM}$ of $\mathrm{Na}_{2} \mathrm{SO}_{4}$ as the electron acceptor. After incubation at $25^{\circ} \mathrm{C}$ for 3 weeks, the utilization of the electron donors was determined by the presence of sulfide ${ }^{15}$ and the cellular growth measured using an Easy-Cyte flow cytometer (Guava Technologies) after staining with 1: 2000 (v/v)-diluted SYBR-Green I (Invitrogen). Thiosulfate disproportionation was tested in the ASW medium supplemented with $10 \mathrm{mM}$ of thiosulfate and the growth was monitored after 1,2, and 3 weeks of incubation using the flow cytometer. Hydrogen-dependent autotrophic growth was tested using the ASW medium under the ambient hydrogen concentration $\left(\mathrm{N}_{2}: \mathrm{H}_{2}: \mathrm{CO}_{2}=90: 5: 5\right)$ in the anaerobic chamber, and the growth was measured using the flow cytometer after incubation at $25^{\circ} \mathrm{C}$ for 3 weeks. Additional biochemical tests were performed using API 20A, API ZYM, and API 50CH test strips (bioMérieux) according to the instructions of the manufacturers except that ASW was used as the suspension medium for the API ZYM test and cysteine as the reducing agent for the API 50CH medium. The results of the tests were recorded after 2 weeks of incubation at $25^{\circ} \mathrm{C}$ under anaerobic conditions.

Chemotaxonomic characterization. The fatty-acid methyl ester (FAME) profiles of the bacteria were determined via gas chromatography (Agilent 7890A) by using Sherlock Microbial Identification System version 6.1 (MIDI) with the TSBA6 database according to the manufacturer's protocol ${ }^{61}$. For FAME analysis, the cells of IMCC $35004^{\mathrm{T}}$, IMCC $35005^{\mathrm{T}}$, Desulfopila aestuarii DSM $18488^{\mathrm{T}}$, and Desulfotalea psychrophila DSM $12343^{\mathrm{T}}$ were harvested from colonies grown on the same sectors of the plates after anaerobic incubation on MA at $25^{\circ} \mathrm{C}$ $\left(15^{\circ} \mathrm{C}\right.$ for Desulfotalea psychrophila DSM $\left.12343^{\mathrm{T}}\right)$ for 3 weeks. Polar lipids were extracted according to the proto- 
col described by Minnikin et al. ${ }^{62}$ and separated using two-dimensional TLC on silica-gel $60 \mathrm{~F}_{254}$ plates (Merck). All the polar lipids on the TLC plates were visualized by spraying the plates with molybdatophosphoric acid. The aminolipids, phospholipids, and glycolipids on replicate TLC plates were identified by spraying the plates with ninhydrin, molybdenum blue, and alpha-naphthol solution, respectively. Respiratory isoprenoid quinones were extracted $^{62}$ and examined via reverse-phase partition chromatography by using HPTLC RP-18F ${ }_{254}$ (Merck), according to the method described by Collins et al. ${ }^{63}$.

Nucleotide sequence accession numbers. The 16S rRNA gene sequences and the whole-genome sequences of strains IMCC $35004^{\mathrm{T}}$ and IMCC $35005^{\mathrm{T}}$ were deposited in GenBank/EMBL/DDBJ under the accession numbers MK660563 and MK660564, and CP050699 and CP050698, respectively.

Received: 4 May 2021; Accepted: 27 September 2021

Published online: 07 October 2021

\section{References}

1. Ingvorsen, K., Yde Nielsen, M. \& Joulian, C. Kinetics of bacterial sulfate reduction in an activated sludge plant. FEMS Microbiol. Ecol. 46, 129-137 (2003)

2. Figliuolo, V. R. et al. Sulfate-reducing bacteria stimulate gut immune responses and contribute to inflammation in experimental colitis. Life Sci. 189, 29-38 (2017).

3. Karna, R. R. et al. Microbial population dynamics and the role of sulfate reducing bacteria genes in stabilizing $\mathrm{Pb}, \mathrm{Zn}$, and $\mathrm{Cd}$ in the terrestrial subsurface. Soil Syst. 2, 60 (2018).

4. Kim, Y. J. et al. Paradesulfovibrio onnuriensis gen. nov., sp. nov., a chemolithoautotrophic sulfate-reducing bacterium isolated from the Onnuri vent field of the Indian Ocean and reclassification of Desulfovibrio senegalensis as Paradesulfovibrio senegalensis comb. nov. J. Microbiol. 58, 252-259 (2020).

5. Müller, H., Marozava, S., Probst, A. J. \& Meckenstock, R. U. Groundwater cable bacteria conserve energy by sulfur disproportionation. ISME J. 14, 623-634 (2020).

6. Jiang, L. et al. Vertical distribution and diversity of sulfate-reducing prokaryotes in the Pearl River estuarine sediments, Southern China. FEMS Microbiol. Ecol. 70, 249-262 (2009).

7. Leloup, J. et al. Sulfate-reducing bacteria in marine sediment (Aarhus Bay, Denmark): Abundance and diversity related to geochemical zonation. Environ. Microbiol. 11, 1278-1291 (2009).

8. Kleindienst, S., Ramette, A., Amann, R. \& Knittel, K. Distribution and in situ abundance of sulfate-reducing bacteria in diverse marine hydrocarbon seep sediments. Environ. Microbiol. 14, 2689-2710 (2012).

9. Jørgensen, B. B. Mineralization of organic matter in the sea bed-the role of sulphate reduction. Nature 296, 643-645 (1982).

10. Muyzer, G. \& Stams, A. J. The ecology and biotechnology of sulphate-reducing bacteria. Nat. Rev. Microbiol. 6, 441-454 (2008).

11. Waite, D. W. et al. Proposal to reclassify the proteobacterial classes Deltaproteobacteria and Oligoflexia, and the phylum Thermodesulfobacteria into four phyla reflecting major functional capabilities. Int. J. Syst. Evol. Microbiol. 70, 5972-6016 (2020).

12. Friedrich, M., Springer, N., Ludwig, W. \& Schink, B. Phylogenetic positions of Desulfofustis glycolicus gen. nov., sp. nov. and Syntrophobotulus glycolicus gen. nov., sp. nov., two new strict anaerobes growing with glycolic acid. Int. J. Syst. Evol. Microbiol. 46, 1065-1069 (1996).

13. Janssen, P. H., Schuhmann, A., Bak, F. \& Liesack, W. Disproportionation of inorganic sulfur compounds by the sulfate-reducing bacterium Desulfocapsa thiozymogenes gen. nov., sp. nov. Arch. Microbiol. 166, 184-192 (1996).

14. Isaksen, M. F. \& Teske, A. Desulforhopalus vacuolatus gen. nov., sp. nov., a new moderately psychrophilic sulfate-reducing bacterium with gas vacuoles isolated from a temperate estuary. Arch. Microbiol. 166, 160-168 (1996).

15. Knoblauch, C., Sahm, K. \& Jørgensen, B. B. Psychrophilic sulfate-reducing bacteria isolated from permanently cold Arctic marine sediments: Description of Desulfofrigus oceanense gen. nov., sp. nov., Desulfofrigus fragile sp. nov., Desulfofaba gelida gen. nov., sp. nov., Desulfotalea psychrophila gen. nov., sp. nov. and Desulfotalea arctica sp. nov. Int. J. Syst. Evol. Microbiol. 49, 1631-1643 (1999).

16. Suzuki, D., Ueki, A., Amaishi, A. \& Ueki, K. Desulfopila aestuarii gen. nov., sp. nov., a Gram-negative, rod-like, sulfate-reducing bacterium isolated from an estuarine sediment in Japan. Int. J. Syst. Evol. Microbiol. 57, 520-526 (2007).

17. Yoon, S. H. et al. Introducing EzBioCloud: A taxonomically united database of 16S rRNA gene sequences and whole-genome assemblies. Int. J. Syst. Evol. Microbiol. 67, 1613-1617 (2017).

18. Kovacik, W. P. Jr. et al. Molecular analysis of deep subsurface Cretaceous rock indicates abundant Fe(III)- and $S^{0}$-reducing bacteria in a sulfate-rich environment. Environ. Microbiol. 8, 141-155 (2006).

19. Orcutt, B. N., D’Angelo, T., Wheat, C. G. \& Trembath-Reichert, E. Microbe-mineral biogeography from multi-year incubations in oceanic crust at North Pond, Mid-Atlantic Ridge. Environ. Microbiol. 23, 3923-3936 (2021).

20. Kim, B. S., Oh, H. M., Kang, H., Park, S. S. \& Chun, J. Remarkable bacterial diversity in the tidal flat sediment as revealed by $16 \mathrm{~S}$ rDNA analysis. J. Microbiol. Biotechnol. 14, 205-211 (2004).

21. Zhang, Y. et al. Microbial diversity in cold seep sediments from the northern South China Sea. Geosci. Front. 3, $301-316$ (2012).

22. Sun, F. et al. Seagrass (Zostera marina) colonization promotes the accumulation of diazotrophic bacteria and alters the relative abundances of specific bacterial lineages involved in benthic carbon and sulfur cycling. Appl. Environ. Microbiol. 81, 6901-6914 (2015).

23. Stackebrandt, E. \& Ebers, J. Taxonomic parameters revisited: Tarnished gold standards. Microbiol. Today 33, 152-155 (2006).

24. Kim, M., Oh, H. S., Park, S. C. \& Chun, J. Towards a taxonomic coherence between average nucleotide identity and $16 \mathrm{~S}$ rRNA gene sequence similarity for species demarcation of prokaryotes. Int. J. Syst. Evol. Microbiol. 64, 346-351 (2014).

25. Wayne, L. G. et al. Report of the ad hoc committee on reconciliation of approaches to bacterial systematics. Int. J. Syst. Evol. Microbiol. 37, 463-464 (1987).

26. Chun, J. et al. Proposed minimal standards for the use of genome data for the taxonomy of prokaryotes. Int. J. Syst. Evol. Microbiol. 68, 461-466 (2018).

27. Qin, Q. L. et al. A proposed genus boundary for the prokaryotes based on genomic insights. J. Bacteriol. 196, 2210-2215 (2014).

28. Konstantinidis, K. T., Rosselló-Móra, R. \& Amann, R. Uncultivated microbes in need of their own taxonomy. ISME J. 11, 2399-2406 (2017).

29. Gittel, A. et al. Desulfopila inferna sp. nov., a sulfate-reducing bacterium isolated from the subsurface of a tidal sand-flat. Int. J. Syst. Evol. Microbiol. 60, 1626-1630 (2010)

30. Lie, T. J., Clawson, M. L., Godchaux, W. \& Leadbetter, E. R. Sulfidogenesis from 2-aminoethanesulfonate (taurine) fermentation by a morphologically unusual sulfate-reducing bacterium, Desulforhopalus singaporensis sp. nov. Appl. Environ. Microbiol. 65, 3328-3334 (1999). 
31. Finster, K., Liesack, W. \& Thamdrup, B. Elemental sulfur and thiosulfate disproportionation by Desulfocapsa sulfoexigens sp. nov., a new anaerobic bacterium isolated from marine surface sediment. Appl. Environ. Microbiol. 64, 119-125 (1998).

32. Rabus, R. et al. A post-genomic view of the ecophysiology, catabolism and biotechnological relevance of sulphate-reducing prokaryotes. Adv. Microb. Physiol. 66, 55-321 (2015).

33. Santos, A. A. et al. A protein trisulfide couples dissimilatory sulfate reduction to energy conservation. Science 350, 1541-1545 (2015).

34. Anantharaman, K. et al. Expanded diversity of microbial groups that shape the dissimilatory sulfur cycle. ISME J. 12, 1715-1728 (2018).

35. Kim, B. S. et al. Rapid phylogenetic dissection of prokaryotic community structure in tidal flat using pyrosequencing. J. Microbiol. 46, 357-363 (2008).

36. Weisburg, W. G., Barns, S. M., Pelletier, D. A. \& Lane, D. J. 16 S ribosomal DNA amplification for phylogenetic study. J. Bacteriol. 173, 697-703 (1991).

37. Pruesse, E., Peplies, J. \& Glöckner, F. O. SINA: Accurate high-throughput multiple sequence alignment of ribosomal RNA genes. Bioinformatics 28, 1823-1829 (2012).

38. Ludwig, W. et al. ARB: A software environment for sequence data. Nucleic Acids Res. 32, 1363-1371 (2004).

39. Kumar, S., Stecher, G., Li, M., Knyaz, C. \& Tamura, K. MEGA X: Molecular evolutionary genetics analysis across computing platforms. Mol. Biol. Evol. 35, 1547-1549 (2018).

40. Saitou, N. \& Nei, M. The neighbor-joining method: A new method for reconstructing phylogenetic trees. Mol. Biol. Evol. 4, 406-425 (1987).

41. Felsenstein, J. Evolutionary trees from DNA sequences: a maximum likelihood approach. J. Mol. Evol. 17, 368-376 (1981).

42. Rzhetsky, A. \& Nei, M. Theoretical foundation of the minimum-evolution method of phylogenetic inference. Mol. Biol. Evol. 10, 1073-1095 (1993).

43. Felsenstein, J. Confidence limits on phylogenies: An approach using the bootstrap. Evolution 39, 783-791 (1985).

44. Walters, W. et al. Improved bacterial $16 \mathrm{~S}$ rRNA gene (V4 and V4-5) and fungal internal transcribed spacer marker gene primers for microbial community surveys. mSystems 1, e00009-15 (2015).

45. Bolyen, E. et al. Reproducible, interactive, scalable and extensible microbiome data science using QIIME 2. Nat. Biotechnol. 37, 852-857 (2019).

46. Martin, M. Cutadapt removes adapter sequences from high-throughput sequencing reads. EMBnet. J. 17, 10-12 (2011).

47. Callahan, B. J. et al. DADA2: High-resolution sample inference from Illumina amplicon data. Nat. Methods 13, 581-583 (2016).

48. Wick, R. R., Judd, L. M., Gorrie, C. L. \& Holt, K. E. Unicycler: Resolving bacterial genome assemblies from short and long sequencing reads. PLoS Comput. Biol. 13, e1005595 (2017).

49. Richter, M., Rosselló-Móra, R., Oliver Glöckner, F. \& Peplies, J. JSpeciesWS: A web server for prokaryotic species circumscription based on pairwise genome comparison. Bioinformatics 32, 929-931 (2016).

50. Meier-Kolthoff, J. P., Auch, A. F., Klenk, H. P. \& Göker, M. Genome sequence-based species delimitation with confidence intervals and improved distance functions. BMC Bioinform. 14, 60 (2013).

51. Rodriguez-R, L. M. \& Konstantinidis, K. T. Bypassing cultivation to identify bacterial species. Microbe 9, 111-118 (2014).

52. Na, S. I. et al. UBCG: Up-to-date bacterial core gene set and pipeline for phylogenomic tree reconstruction. J. Microbiol. 56, 280-285 (2018).

53. Seemann, T. Prokka: Rapid prokaryotic genome annotation. Bioinformatics 30, 2068-2069 (2014).

54. Kanehisa, M., Sato, Y. \& Morishima, K. BlastKOALA and GhostKOALA: KEGG tools for functional characterization of genome and metagenome sequences. J. Mol. Biol. 428, 726-731 (2016).

55. Aramaki, T. et al. KofamKOALA: KEGG ortholog assignment based on profile HMM and adaptive score threshold. Bioinformatics 36, 2251-2252 (2019).

56. Marchler-Bauer, A. et al. CDD: Conserved domains and protein three-dimensional structure. Nucleic Acids Res. 41, 348-352 (2013).

57. Emms, D. M. \& Kelly, S. OrthoFinder: Phylogenetic orthology inference for comparative genomics. Genome Biol. 20, 238 (2019).

58. Carini, P., Steindler, L., Beszteri, S. \& Giovannoni, S. J. Nutrient requirements for growth of the extreme oligotroph 'Candidatus Pelagibacter ubique' HTCC1062 on a defined medium. ISME J. 7, 592-602 (2013).

59. Davis, H. C. \& Guillard, R. R. Relative value of ten genera of micro-organisms as foods for oyster and clam larvae. USFWS Fish Bull. 58, 293-304 (1958).

60. Cord-Ruwisch, R. A quick method for the determination of dissolved and precipitated sulfides in cultures of sulfate-reducing bacteria. J. Microbiol. Methods 4, 33-36 (1985).

61. Sasser, M. Identification of bacteria by gas chromatography of cellular fatty acids. In MIDI Technical Note 101. (MIDI Inc, 1990).

62. Minnikin, D. et al. An integrated procedure for the extraction of bacterial isoprenoid quinones and polar lipids. J. Microbiol. Methods 2, 233-241 (1984).

63. Collins, M. D., Shah, H. N. \& Minnikin, D. E. A note on the separation of natural mixtures of bacterial menaquinones using reverse phase thin-layer chromatography. J. Appl. Bacteriol. 48, 277-282 (1980).

\section{Acknowledgements}

We thank Dr. Aharon Oren from The Hebrew University of Jerusalem (Israel) for his help on the nomenclatures of the new species. This research was supported by the Collaborative Genome Program of the Korea Institute of Marine Science and Technology Promotion (KIMST), funded by the Ministry of Oceans and Fisheries (MOF) (No. 20180430), and also by National Research Foundation of Korea (NRF) Grants (NRF-2019R1A2B5B02070538 and NRF-2018R1A5A1025077 to J-CC, and NRF-2020R1I1A1A01073389 to JS).

\section{Author contributions}

Conceptualization, J.S. and J.H.; methodology, J.S. and J.H.; software, I.K.; writing-original draft preparation, J.S. and J.H.; formal analysis, J.S. and J.H.; writing-review and editing, J.S. and J.-C.C.; supervision, J.-C.C.; funding acquisition, J.S. and J.-C.C. All authors have read and agreed to the published version of the manuscript.

\section{Competing interests}

The authors declare no competing interests.

\section{Additional information}

Supplementary Information The online version contains supplementary material available at https:/doi.org/ 10.1038/s41598-021-99469-5. 
Correspondence and requests for materials should be addressed to J.-C.C.

Reprints and permissions information is available at www.nature.com/reprints.

Publisher's note Springer Nature remains neutral with regard to jurisdictional claims in published maps and institutional affiliations.

(c) (i) Open Access This article is licensed under a Creative Commons Attribution 4.0 International cc) License, which permits use, sharing, adaptation, distribution and reproduction in any medium or format, as long as you give appropriate credit to the original author(s) and the source, provide a link to the Creative Commons licence, and indicate if changes were made. The images or other third party material in this article are included in the article's Creative Commons licence, unless indicated otherwise in a credit line to the material. If material is not included in the article's Creative Commons licence and your intended use is not permitted by statutory regulation or exceeds the permitted use, you will need to obtain permission directly from the copyright holder. To view a copy of this licence, visit http://creativecommons.org/licenses/by/4.0/.

(C) The Author(s) 2021 